\title{
GAMBARAN EPIDEMIOLOGI DAN STIGMA SOSIAL TERKAIT PANDEMI COVID- 19 DI KOTA TANGERANG SELATAN TAHUN 2020
}

\author{
${ }^{1)}$ Astri Kurnia Sari, ${ }^{2)}$ Thresya Febrianti \\ ${ }^{1,2)}$ Program Studi Kesehatan Masyarakat, Fakultas Kesehatan Masyarakat, Universitas Muhammadiyah Jakarta \\ ${ }^{1,2)}$ Jl. K.H. Ahamad Dahlan, Cirendeu, Kec. Ciputat Timur, Kota Tangerang Selatan - Banten - Indonesia \\ E-mail : ${ }^{1)}$ astrikurnia11@gmail.com,${ }^{2)}$ thresya.febrianti89@gmail.com
}

Kata Kunci:

epidemiologi, stigma sosial, pandemi, COVID-19
Keywords:

epidemiology, social stigma, pandemic, COVID-19

\section{Info Artikel}

Tanggal dikirim: 15-9-2020

Tanggal direvisi: 22-9-2020

Tanggal diterima: 29-9-2020 DOI Artikel:

10.36341/cmj.v3i3.1506 Attribution-NonCommercial $4.0 \quad$ International. Some rights reserved

\begin{abstract}
ABSTRAK
Pada bulan Desember 2019 ditemukan kasus peneumonia yang tidak diketahui etiologinya muncul di Wuhan, Hubei, China dengan gejala klinis yang sangat menyerupai pneumonia yang diberi nama COVID-19. Pandemi COVID-19 dapat menimbulkan perasaan takut akan tertular, kecemasan, stigma, prasangka dan marginalisasi terhadap penyakit pada pasien, orang berisiko dan orang yang sehat hingga tenaga kesehatan. Penelitian ini bertujuan untuk melihat gambaran epidemiologi dan stigma sosial terkait pandemi COVID-19 di Kota Tangerang Selatan tahun 2020. Penelitian ini merupakan jenis penelitian kuantitatif dengan metode deskriptif dengan pendekatan cross sectional. Penelitian dilakukan pada bulan Juli 2020. Populasi dalam penelitian ini adalah masyarakat Kota Tangerang Selatan. Sampel yang digunakan adalah sebesar 107 responden dengan teknik pengambilan sampel purposive sampling. Pengambilan data menggunakan kuesioner melalui google form. Hasil penelitian menjukkan sebagian besar responden berusia 17-25 tahun sebanyak 73,8\%, jenis kelamin respoden sebagian besar adalah perempuan sebanyak 70,1\%, status pekerjaan responden sebagian besar adalah pelajar/mahasiswa sebanyak $60,7 \%$ dan wilayah kecamatan yang ditinggali responden sebagian besar berada di Kecamatan Pamulang sebanyak 29,0\%. Selain itu, masyarakat yang tidak memiliki stigma pada pasien COVID-19 sebanyak 56,1\%. Diharapkan masyarakat tetap waspada dan menjalankan protokol kesehatan selama masa pandemi COVID-19 dan menghindari memberi stigma pada pasien COVID-19 agar menghindari seseorang menyembunyikan status kesehatannya.
\end{abstract}

\begin{abstract}
In December 2019, a case of peneumonia of unknown etiology was found in Wuhan, Hubei, China with clinical symptoms that closely resemble pneumonia, which is named COVID-19. The COVID-19 pandemic can cause feelings of fear of infection, anxiety, stigma, prejudice and marginalization of disease in patients, people at risk and healthy people to health workers. This study aims to describe the epidemiology and social stigma associated with the COVID-19 pandemic in South Tangerang City in 2020. This research is a type of quantitative research with a descriptive method with a cross sectional approach. The study was conducted in July 2020. The population in this study were the people of South Tangerang City. The sample used was 107 respondents with purposive sampling technique. Retrieval of data using a questionnaire via google form. Based on the results of the study, $73.8 \%$ of the respondents were $17-25$ years old, $70.1 \%$ of the respondents were female. , the occupational status of the respondents is mostly students as much as $60.7 \%$ and the sub-districts where the respondents are mostly residing in Pamulang is 29.0\%. People who do not have a stigma on COVID-19 patients are $56.1 \%$. It is hoped that the public will remain vigilant and carry out health protocols during the COVID-19 pandemic and avoid stigmatizing COVID-19 patients in order to avoid someone hiding their health status.
\end{abstract}

\section{PENDAHULUAN}

Pada bulan Desember 2019 ditemukan kasus peneumonia yang tidak diketahui etiologinya muncul di Wuhan,
Hubei, China dengan gejala klinis yang sangat menyerupai pneumonia. Kemudian World Health Organization (WHO) menetapkan sebagai Kedaruratan 
Masyarakat Yang Meresahkan atau Public Health Emergency of International Concern [1]. Kasus yang tekonfirmasi positif COVID-19 di dunia per tanggal 08 Oktober 2020 dengan 35.659.007 total kasus, dan 1.044.269 kematian [2] Sementara itu, di Indonesia kasus pertama terkonfirmasi pada tanggal 2 Maret 2020 dan jumlah kasus positif COVID-19 per tanggal 08 Oktober 2020 adalah 315.714 dan 11.472 kematian [3]. Kota Tangerang Selatan merupakan kota dengan peningkatan kasus yang terkonfirmasi COVID-19 tertinggi di Provinsi Banten dengan total kasus sampai dengan 08 Oktober 2020 sebanyak 1234 pasien positif dan 61 pasien meninggal [4].

Ketidakpastian wabah seperti presentasi klinis, penyebab infeksi, gambaran epidemiologi, pola transmisi yang cepat, keseriusan dampak bagi kesehatan masyarakat dan ketidaksiapan fasilitas kesehatan dalam mengahadapi pandemi dapat berdampak pada psikologis seseorang. Pandemi ini juga dapat menimbulkan perasaan takut akan tertular, kecemasan, stigma, prasangka dan marginalisasi terhadap penyakit pada pasien, orang berisiko dan orang yang sehat hingga tenaga kesehatan [5].

Stigma sosial merupakan hubungan negatif antara seseorang atau sekelompok orang dengan karakteristik tertentu dan penyakit tertentu serta pelebelan, stereotip, dan diskriminasi terhadap seseorang karena dianggap memiliki hubungan dengan suatu penyakit. Pada kasus pandemi COVID-19 ini memicu stigma sosial dan diskriminasi terhadap orangorang dari latar belakang tertentu serta siapapun yang telah diangap melakukan kontak dengan virus [6].

Pada penelitian yang dilakukan oleh Geldsetzer di Amerika dan Inggris masih ditemukan sikap diskriminasi terhadap etnis Asia Timur karena merasa takut akan tertular [7]. Kemudian, pemberian frasa virus yang tidak tepat dapat menciptakan stigma dan pelabelan pada etnis tertentu. Seperti penggunaan frasa "Chinese virus" oleh Presiden Amerika Serikat yang ditulis di akun Tweeter-nya. Hal ini memicu masyarakat juga menggunakan frasa tersebut. Budhwani dan Sun melakukan penelitian melalui platform Twitter dari lima puluh negara bagian Amerika Serikat untuk mengetahui peningkatan penggunaan frasa tersebut setelah frasa tersebut digunakan oleh Presiden Amerika dengan megekstrak tweet yang menyebutkan "Chinese virus" atau "China virus" dan didapatkan peningkatan hampir 10 kali [8]. Hal ini merupakan bentuk dari pelabelan terhadap suatu suku tertentu.

Penelitian yang dilakukan Idris dan Jalli melalui platform Twitter dengan melihat percakapan yang mengarah stigma terkait COVID-19 menyebutkan bahwa sebanyak $(83,3 \%)$ masyarakat Indonesia memberikan stigma dalam bentuk pelabelan [9]. Pemberian stigma akan berpengaruh terhadap orang yang terstigma untuk menyembunyikan penyakit agar terhindar diskriminasi, dan menolak untuk mencari perawatan kesehatan segera, serta enggan menerapkan perilaku hidup bersih dan sehat (PHBS) [10].

Berdasarkan masalah yang telah diuraikan, maka peneliti tertarik melakukan penelitian tentang gambaran epidemiologi dan stigma sosial terkait COVID-19 di Kota Tangerang Selatan.

\section{METODE}

Penelitian ini merupakan jenis penelitian kuantitatif dengan metode deskriptif dengan pendekatan cross sectional. Penelitian dilakukan pada bulan Juli 2020. Populasi dalam penelitian ini adalah masyarakat Kota Tangerang Selatan. Sampel yang digunakan adalah sebesar 107 responden dengan teknik pengambilan sampel purposive sampling dengan kriteria berdomisili di Kota Tangerang Selatan dan berusia $\geq 17$ tahun. Pengambilan data menggunakan kuesioner berbasis online google form. Variabel stigma terdiri dari 6 pernyataan yang dikategorikan menjadi stigma dan tidak berstigma dengan cut of point 
menggunakan median. Data dianalisis secara univariat. Penelitian ini sudah

\section{HASIL DAN PEMBAHASAN}

\section{Hasil}

Berdasarkan Tabel 1 menunjukan bahwa sebagian besar responden berusia remaja akhir pada rentang usia 17-25 tahun sebanyak 79 orang $(73,8 \%)$, kemudian sebagian besar responden adalah tamat SMA/sederajat sebanyak 72 (67,3\%), melalui persetuan etik dengan No.10.096.B/KEPK-FKMUMJ/VII/2020.

Tabel 1. Karakteristik Responden

\begin{tabular}{ccc}
\hline Variabel & F & \% \\
\hline Umur & 79 & 73,8 \\
$17-25$ tahun & 25 & 23,4 \\
$26-35$ tahun & 1 & 0,9 \\
$36-45$ tahun & 2 & 1,9 \\
$46-55$ tahun & 32 & 29,9 \\
Jenis Kelamin & 75 & 70,1 \\
Laki - laki & & \\
Perempuan & 0 & 0 \\
Tingkat Pendidikan & 1 & 0,9 \\
Tidak Tamat SD & 0 & 0 \\
Tamat SD/Sederajat & 72 & 67,3 \\
Tamat SMP/Sederajat & 34 & 31,8 \\
Tamat SMA/Sederajat & & \\
Tamat Perguruan Tinggi & 65 & 60,7 \\
Status Pekerjaan & 26 & 24,3 \\
Pelajar/mahasiswa & 2 & 1,9 \\
Karyawan Swasta & 6 & 5,6 \\
PNS & 8 & 7,5 \\
Wiraswasta & & \\
Lainnya & 19 & 17,8 \\
Wilayah Kecamatan & 15 & 14,0 \\
Ciputat & 31 & 29,0 \\
Ciputat Timur & 15 & 14,0 \\
Pamulang & 8 & 9,5 \\
Pondok Aren & 10 & 8,4 \\
Serpong & 9 &
\end{tabular}

Tabel 2. Distribusi Stigma Sosial

\begin{tabular}{ccc}
\hline Stigma Sosial & N & \% \\
\hline Stigma & 47 & 43,9 \\
\hline Tidak stigma & 60 & 56,1 \\
\hline
\end{tabular}


Berdasarkan Tabel 2 sebagian besar responden tidak memiliki stigma terhadap pasien COVID-19 sebanyak 60 orang $(56,1 \%)$ sedangkan jumlah responden yang memberi stigma sebanyak 47 orang $(43,9 \%)$.

\section{Pembahasan}

1. Umur

Berdasarkan hasil penelitian, mayoritas responden berusia 17-25 tahun sebanyak 79 orang $(73,8 \%)$. Menurut Depkes RI umur tersebut merupakan kategori masa remaja akhir [11]. Umur merupakan salah satu faktor seseorang dalam memberi persepsi dan stigma. Semakin bertambah usia seseorang, maka sikap dan perilaku semakin berubah pula sehingga pemikiran seseorang dapat berubah [12]. Umur secara alamiah berpengaruh terhadap kinerja fisik serta perilaku seseorang.

2. Jenis Kelamin

Berdasarkan hasil penelitian, jumlah responden perempuan lebih tinggi sebanyak 75 orang $(70,1 \%)$. Menurut Mufidati, jenis kelamin mempengaruhi salah satu komponen dari persepsi yakin komponen afektif atau emosi. Emosi mempengaruhi persepsi seseorang. Laki-laki cenderung dapat mengendalikan emosinya dibandingkan perempuan [13]. Menurut Andrewin et al dalam Salmon et al perempuan cenderung memiliki stigma lebih tinggi dalam arti bersikap menyalahkan dibandingkan dengan laki-laki [14] .

3. Tingkat Pendidikan

Berdasarkan hasil penelitian, tingkat pendidikan dalam penelitian ini menunjukan mayoritas adalah tamat SMA/sederajat sebanyak 72 orang (67,3\%). Menurut Potter dan Perry dalam Nurhidayat tingkat pendidikan merupakan salah satu faktor interpersonal yang dapat mempengaruhi persepsi seseorang [15]. Seseorang yang berpendidikan tinggi dapat mempengaruhi tingkat pengetahuan serta persepsi dalam memahami suatu informasi tentang pandemi COVID-19.

4. Status Pekerjaan

Berdasarkan hasil penelitian, mayoritas adalah pelajar/mahasiswa sebanyak 65 orang $(60,7 \%)$. Mayoritas responden yang memiliki status sebagai pelajar/mahasiswa sehingga responden dapat lebih mudah menjangkau informasi terkait COVID-19 yang kemudian dapat mempengaruhi pandangan terhadap pasien COVID-19.

5. Stigma Sosial

Berdasarkan hasil penelitian, sebagian besar responden yang tidak berstigma pada pasien COVID-19 sebanyak 60 orang $(56,1 \%)$. Masyarakat berpendapat tidak setuju jika merahasiakan status apabila terdapat anggota keluarga yang terinfeksi $(42,1 \%)$, masyarakat berpendapat sangat tidak setuju apabila pasien yang terinfeksi COVID-19 akan diasingkan $(43,9 \%)$, masyarakat berpendapat sangat tidak setuju bahwa pasien COVID-19 dapat mencoreng nama baik kawasan mereka (52,3\%), masyarakat berpendapat sangat tidak setuju jika pasien COVID-19 disalahkan atas penyakitnya $(53,3 \%)$, masyarakat berpendapat sangat tidak setuju jika merasa malu apabila terdapat keluarga yang terinfeksi (53,3\%). Namun, terdapat masyarakat yang berpendapat setuju jika orang-orang masih berprasangka buruk terhadap pasien COVID-19 (43,9\%). Hal ini merupakan bentuk stereotip karena merupakan suatu bentuk gagasan mengenai individu atau sekelompok orang dalam membuat impresi dan ekspektasi. Stereotip dapat menyebabkan individu merasa terancam dan ketakutan akan diadili atas stereotip tersebut. Stereotip mengasumsikan bahwa stigma menempatkan seseorang pada risiko 
mengalami ancaman terhadap identitas sosialnya [16]. Maka, dapat disimpulkan bahwa hal ini terjadi karena masyarakat merasa terancam kemudian menimbulkan persepsi bahwa mereka biasa saja tertular sehingga terciptanya stigma bahwa pasien COVID-19 dipandang buruk.

\section{KESIMPULAN}

Mayoritas responden berusia 17-25 tahun sebanyak $73,8 \%$, berdasarkan jenis kelamin sebagian besar responden adalah perempuan sebanyak $70,1 \%$, berdasarkan status pekerjaan sebagian besar responden merupakan pelajar/mahasiswa sebanyak $60,7 \%$, dan responden berdasarkan Wilayah Kecamatan adalah di Kecamatan Pamulang sebanyak 29,0\%. Masyarakat yang tidak memberi stigma pada pasien COVID-19 sebanyak 56,1\%. Disarankan masyarakat untuk menghindari masyarakat memberi stigma pada pasien COVID-19 agar menghindari seseorang menyembunyikan status kesehatannya.dan tetap waspada dan menjalankan protokol kesehatan selama masa pandemi COVID-19.

\section{DAFTAR PUSTAKA}

[1] Kementerian Kesehatan RI, Pedoman Kesiapsiagaan Menghadapi Coronavirus Disease (Covid-19). 2020.

[2] WHO, "WHO Coronavirus Disease (Covid-19) Dashboard," 2020. [Online]. Available: https://covid19.who.int/. [Accessed: 08-Oct-2020].

[3] Satgas Covid-19, "Peta Sebaran Covid-19," 07 October 2020, 2020. [Online]. Available: https://covid19.go.id/peta-sebaran. [Accessed: 08-Oct-2020].

[4] Pemerintah Kota Tangsel, "Tangsel Tanggap Covid-19," 08 October 2020, 2020. [Online]. Available: https://lawancovid19.tangerangselatan kota.go.id/. [Accessed: 08-Oct-2020].
[5] W. Rana, S. Mukhtar, And S. Mukhtar, "Mental Health Of Medical Workers In Pakistan During The Pandemic Covid- 19 Outbreak," No. January, Pp. 19-21, 2020.

[6] WHO, "Social Stigma Associated With Covid-19 A Guide To Preventing And Addressing," No. February, Pp. 1-5, 2020.

[7] P. Geldsetzer, "Knowledge And Perceptions Of Covid-19 Among The General Public In The United States And The United Kingdom: A CrossSectional Online Survey," Vol. 6, No. March, Pp. 2-5, 2020.

[8] H. Budhwani And R. Sun, "Referencing The Novel Coronavirus As The ' Chinese Virus ' Or ' China Virus ' On Twitter: Covid-19 Stigma Table Of Contents," 2020.

[9] I. K. Idris And N. Jalli, "Riset Covid19: Sikap Menyalahkan Orang Lain Dominan Di Percakapan Twitter Di Indonesia Dan Malaysia," 28 April 2020, 2020. [Online]. Available: https://theconversation.com/risetcovid-19-sikap-menyalahkan-oranglain-dominan-di-percakapan-twitterdi-indonesia-dan-malaysia-137385. [Accessed: 12-Jun-2020].

[10] WHO, "Coronavirus Disease 2019 (Covid-19) Situation Report - 35," 2020.

[11] Depkes RI, Klasifikasi Umur Menurut Kategori. Jakarta: Ditjen Yankes, 2009.

[12] M. K. Intani, "Karya Tulis Ilmiah Stigma Perawat Tentang Pasien HIV,"

Program Studi Ilmu Keperawatan Fakultas Kedokteran Dan Ilmu Kesehatan Universitas Muhammadiyah Yogyakarta, 2017.

[13] H. Mufidati, "Faktor-Faktor Yang Berhubungan Dengan Persepsi Masyarakat Mengenai Filariasis Di RW 03 Desa Cimanggis," Universitas Islam Negeri Syarif Hidayatullah, 2016. 
[14] D. Salmon, G. D. Kandou, H. M. . Palandeng, And Z. C. J. . Porajow, "Hubungan Karakteristik, Pengetahuan Dengan Stigma Petugas Kesehatan Tentang Koinfeksi Tuberkulosis-Virus Human Immunodeficiency Di Kota Manado," J. Kedokt. Komunitas Dan Trop., Vol. II, Pp. 34-39, 2014.

[15] Nurhidayat, "Persepsi Siswa Smp Putra Bangsa Terhadap Perilaku Merokok Di Kelurahan Kemiri Muka Depok," Universitas Indonesia, 2012.

[16] B. Major And L. T. O. Brien, "The Social Psychology Of Stigma," No. February 2005. 